Archaeological Journal

\title{
ObituaryThomas Henry Baylis, V.D., K.C., M.A., F.S.A.
}

\author{
H. H. H.
}

To cite this article: H. H. H. (1908) ObituaryThomas Henry Baylis, V.D., K.C., M.A., F.S.A., Archaeological Journal, 65:1, 339-340, DOI: 10.1080/00665983.1908.10853097

To link to this article: http://dx.doi.org/10.1080/00665983.1908.10853097

曲 Published online: 17 Jul 2014.

Submit your article to this journal ๘

Џ Article views: 2

Q View related articles $\longleftarrow$ 
tinished, although, alas : Mr. Fox died without seeing its final accomplishment. In 1894 the University of Oxford marked its sense of Mr. Fox's work by conferring upon him the honorary degree of a Master of Arts, an honour which he greatly valued and appreciated, and the town of Reading appointed him an honorary curator of the Silchester section of its museum. Although failing health compelled him to retire from active field work at Silchester, he never lost his interest in the excavations, and to the last was always ready with advice and direction as to the conduct of the work. Almost one of his last appearances was a visit to the Silchester exhibition in the rooms of the Society of Antiquaries in June last. Although of a quiet and retiring nature Mr. Fox was an ideal companion, and readily placed his vast knowledge, not only of Roman and medieval antiquities, but also of art, at the service of anyone working on such subjects. All who were associated with him profited from his great experience and knowledge. Mr. Fox passed quietly away on the morning of October 7 th last. Peace to his ashes.

M. S.

\section{THOMAS HENRY BAYLIS, V.D., K.C., M.A., F.S.A.}

The Institute has recently lost some of its oldest veterans. It is assuredly a proof of the rejuvenating influence of archaeological studies that two of our members should have been able to attend our meetings till they were over ninety years old. A short time ago we gave an account in these pages of one of them, our late treasurer, Mr. Hilton. I now propose to say a few words about another one, Judge Baylis. Thomas Henry Baylis was born on the 22nd of June, 1817. He rent to Harrow in 1825, and was there with Cardinal Manning and Anthony Trollope, and to Brasenose College, Oxford, in 1837, where he had won an open scholarship, and where he took his M.A. degree in 1841. He joined the Inner Temple in June, 1834, but remained a special pleader for fifteen years, and was not called to the Bar 
till 1856. He then joined the Northern Circuit, where he had a large practice in commercial cases, and took silk in 1875, was elected a Bencher of the Inner Temple two years later, and became Treasurer in 1899. From 1876 until 1903 he was judge of the Passage Court at Liverpool.

His versatility and alertness were remarkable, and he was interested in many fields. Thus he took part in the suppression of the Chartist riots in 184\%, and when the Volunteer movement was started he joined it, and presently became the colonel of the Paddington regiment: with his father he was one of the founders: of the Fire Brigade. Among lis publications the best known was an interesting account of the Temple Church, which saw several editions. He knew every corner of it, and was a most regular attendant at its services. His acquaintance with John Pascoe, the signal officer of the victory at Trafalgar, led him to write a small polemical book on Nelson's famous signal, a subject on which he was always prepared to have a discussion. He also wrote a well-known handbook on the law of domestic servants.

He was widely interested in archaeology, and had been an intelligent traveller in eastern lands, and used to boast that he had bathed both in the Red Sea and the Jordan. He had been a member of the Archaeological Institute for many years, and no face was morefamiliar or welcome at our meetings both in London and in the country, where he often took part in discussions, which he illuminated by odd and unexpected information. His sharp alert eye and his restless activity were not more remarkable than the urbanity and gentleness with which he treated all whom he met, young and old, gentle and simple. He had a great many friends who well remember his fine handsome face, and who will miss his evergreen temperament and his gentle personality, and none more so than his old pupil and friend the President.

H. H. H. 